\title{
Application of Stable Isotope Tracer to Study Runoff Generation during Different Types of Rainfall Events
}

\author{
Jianfeng Gou ${ }^{1,2}$, Simin Qu ${ }^{1,2}$, Peng Shi ${ }^{1,2, *}$, Dachen $\mathrm{Li}^{1,2}$, Xueqiu Chen ${ }^{1,2}$, Yifan Wang ${ }^{1,2}$, \\ Shuai Shan ${ }^{1,2}$ and Wei $\mathrm{Si}^{1}$ \\ 1 College of Water Resources and Hydrology, Hohai University, Nanjing 210098, China; \\ jf_gou@sina.com (J.G.); wanily@hhu.edu.cn (S.Q.); ldc0814@163.com (D.L.); cxqhhu@163.com (X.C.); \\ wyf3584@163.com (Y.W.); shanshuai@hhu.edu.cn (S.S.); lindongsisi@163.com (W.S.) \\ 2 State Key Laboratory of Hydrology-Water Resources and Hydraulic Engineering, Hohai University, \\ Nanjing 210098, China \\ * Correspondence: ship@hhu.edu.cn
}

Received: 14 March 2018; Accepted: 21 April 2018; Published: 24 April 2018

\begin{abstract}
The main purpose of this study is to explore the runoff generation mechanism and isotopic variation of precipitation during typhoon and plum rain events in the mountainous region mainly covered with bamboo in southeastern China. The isotopic value of precipitation in plum rain events is more depleted than that of precipitation in typhoon events and has a larger range of d-excess. Typhoon events are affected by frequent temperate and tropical cyclones, the ocean evaporationis expected to be very intenseand marine air parcels move very quickly. As for plum rain events, marine air parcel moves slowly due to the blocking effect of the cold front and air moisture evaporated from the continent plays a significant role in the isotope of precipitation depletion process. The difference of stable isotope values in various water sources allows the two-component hydrological separation to quantify the contribution of the event and pre-event water. The results indicate that the pre-event water accounts for at least $60 \%$ of the discharge and the difference in proportion of pre-event water between different types of rain events suggests that the initial state of watershed, rainfall intensity and macropore flow are major control factors of the runoff production mechanism.
\end{abstract}

Keywords: stable isotope; precipitation; hydrograph separation; Hemuqiao watershed; typhoon event; plum rain event

\section{Introduction}

Isotopic value of conservative tracers is mainly affected by mixing different water sources and physical factors such as evaporation, condensate and exchange with other materials [1]. Mixing between different water sources is the major factor affecting the variation of tracer concentration in the hydrological cycle [2]. In the past three decades, stable isotope tracers are used in an experimental watershed by hydrologists to study the runoff generation processes [3-5], to estimate watershed residence time [6-8] and to quantify contributing sources [9]. Most of the studies mainly explore the runoff generation mechanism in the area of relatively small watersheds from $0.01 \mathrm{~km}^{2}$ to $100 \mathrm{~km}^{2}$ [10], and discuss the results of isotopic hydrograph separation which used different tracers in one type of rainfall $[4,11]$. Whereas, using stable tracers $\left({ }^{18} \mathrm{O}\right.$ and $\left.{ }^{2} \mathrm{H}\right)$ in the small watershed to study runoff generation processes in different types of rainfall events is not common. The variation of stable isotopic composition of various water sources during the rainfall events is also used to study groundwater recharge field [12,13] and watershed residence time.

Several studies have investigated the temporal variations of precipitation isotopes in different types of rainfall events [14-16]. Factors affecting the temporal and spatial variation of precipitation 
isotopes mainly included: amount effect, temperature effect, altitude effect and latitude effect $[17,18]$. Especially, processes of air parcel generation, migration, evaporation and exchange with environmental water vapor also strongly influence the variations of the precipitation isotope concentration [19-22]. Since 1961, hydrologists studied water vapor circulation patterns and mechanisms based on global precipitation hydrogen and oxygen stable isotope data which were collected by International Atomic Energy (IAEA) and the World Meteorological Organization (WMO). Yu et al. [23] investigated the variation of the stable isotope in monsoon and non-monsoon precipitation on the south-eastern Tibetan Plateau which indicated that the amount effect plays a more significant role in the change of isotope composition of rainfall than the temperature effect. Wang et al. [24] studied the water vapor trajectory and circulation in Nanjing, the results revealed that the seasonal variation of the stable isotopes of precipitation is mainly affected by the monsoon.

Hydrograph separation study using stable isotopes arose in the early 1970 s $[25,26]$, since then the isotope tracer was widely used as an important diagnostic tool to study the information of different water resources [27]. In many steep mountainous watersheds, runoff is mainly contributed by sub-surface water which flows velocity faster than groundwater $[28,29]$. Many studies discovered that the pre-event water accounted for the majority of the runoff. Hydrograph separation studies using conservative tracers show that some factors have an important impact on the results of the proportion of pre-event water, namely [30]: (1) Catchment size: many hydrologists attempt to establish the relationship between catchment area and event water contribution. In some watersheds, the contribution of event water is positively correlated with watershed area [31]. However, in other watersheds, the contribution of event water is negatively related to the watershed area [32]; (2) Landscape organization: vegetation cover, soil structure, topography and land use play a significant role in event water contribution [8,33,34]; (3) Initial state and characteristics of storm: various studies have found the relationship between event water contribution and the initial state of the watershed, such as antecedent soil moisture [35,36], groundwater level [37], and antecedent streamflow [38]. Characteristics of rainfall also have a significant impact on the results of hydrograph separation.

There are few studies using stable isotope to determine runoff generation mechanism and to quantify water sources in typhoon events and plum rain events in humid watershed covered with bamboo. There are also few studies to analyze the cause of variation in isotopes of rainfall collected during different types of precipitation events. The objectives of this study are: (1) to examine the relationship between the ${ }^{2} \mathrm{H}$ and ${ }^{18} \mathrm{O}$ isotopes of rainfall during typhoon events and plum rain events in Hemuqiao watershed; (2) to quantify the contribution of different water sources for hydrograph separation in different rainfall events and to explore the cause resulting in the difference which will improve our understanding of runoff generation mechanism in different rainfall events.

\section{Study Area}

This study was conducted in Hemuqiao experimental watershed $\left(30^{\circ} 34^{\prime} \mathrm{N}-119^{\circ} 47^{\prime} \mathrm{E}\right)$, located $50-\mathrm{km}$ west of Hangzhou, China, belonging to subtropical monsoon climate (Figure 1). The altitude of this study area $\left(1.35 \mathrm{~km}^{2}\right)$ is between 150 and $600 \mathrm{~m}$. The variation range of temperature and precipitation is large. The lowest temperature in January is about $1.3^{\circ} \mathrm{C}$, and the highest temperature in July is $25^{\circ} \mathrm{C}$. Mean annual precipitation is $1580 \mathrm{~mm}$ which mainly occurs between May and October as rainfall and there is little snow event because of the location of this watershed. The average annual evaporation is about $805 \mathrm{~mm}$ calculated from the evaporation of the water surface.

This watershed is covered mainly by bamboo (90\%), also including potato, tea, and other crops. Some of the bamboos are cut down in September in order to develop local economy and promote people' livelihoods. Along the river channel is a road covered by concrete for transporting the bamboo down from the top of the hill. The type of soil in the upper portion of Hemuqiao watershed is mainly coarse sandy loam and the thickness ranges from 1.5 to $2.5 \mathrm{~m}$, whereas the near channel is mainly covered by volcanic breccia and conglomerates. So, infiltration capacity in this watershed changed with the type of soil. Because of the climatic and vegetation features, the overburden of this watershed 
is mainly in the weakly acidic range from 4.2 to 4.5 [39]. With the increase in altitude, soil organic layer thickness, total nitrogen, total phosphors and ions content increased significantly [39]. The upstream weathering of rocks is quite strong caused by the higher decomposition by vegetation. In addition, the influence of human activities on this watershed could be overlooked.

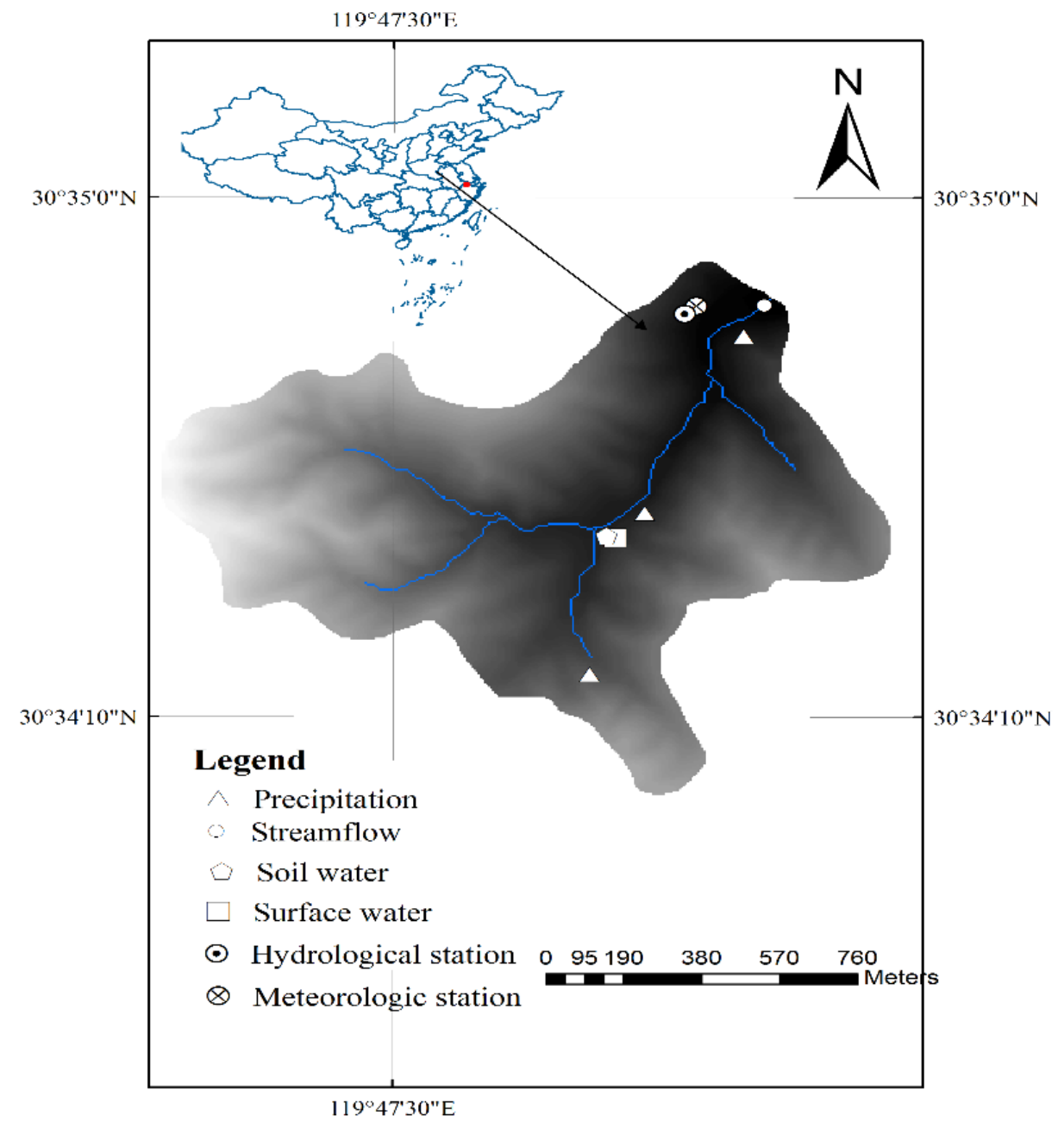

Figure 1. Location of watershed sampling points in Hemuqiao watershed which belongs to typical regions of monsoon.

\section{Methods}

\subsection{Hydrometric Measurements}

Many instruments are installed in the Hemuqiao watershed to monitor the hydrological data. A $90^{\circ}$ sharp crested V-notch weir is used to measure the discharge of this experimental hydrological watershed. The water level in V-notch is recorded every $6 \mathrm{~min}$, and the pressure signal is converted to an electrical signal which is stored in logging devices. Discharge is calculated from the stage-discharge relationship, which is generated when the water level gauge is installed. The long-term data of rainfall are collected by a tipping bucket rain gauge installed in an open area in the upstream. The automatic meteorological station situated at the outlet of this watershed provides long-term monitoring of temperature, radiation and near surface humidity data. 


\subsection{Sampling and Analysis}

Bulk samples of rainfall were collected with a polyethylene barrel whose diameter and height are $50 \mathrm{~cm}$ installed in an open area of Hemuqiao watershed. Bulk samples of throughfall were gathered in the same type of collector installed under the bamboo with medium canopy. In order to demonstrate the temporal variation of isotope concentration in rainfall and throughfall, we take samples at equal time intervals during rainfall events. Rainfall and throughfall samples were collected every hour from 8:00 a.m. to 8:00 p.m. Streamflow water was collected during rainfall events by artificial sampling hourly from 8:00 a.m. to 8:00 p.m. at the outlet of Hemuqiao watershed. The streamflow manual samples start 12 to $20 \mathrm{~h}$ prior to the rainfall events. These water samples are sealed with $30 \mathrm{~mL}$ polyethylene water sampler to prevent evaporation and labeled in order to mark the sampling time. Samples are stored in a refrigerator at $4{ }^{\circ} \mathrm{C}$ in Hohai University before isotopic analysis. Isotope compositions are analyzed by Thermo Fisher MAT 253 (Bremen, Germany) in the State Key Laboratory of Hydrology-Water Resources and Hydraulic Engineering, Hohai University. Isotope compositions of hydrogen and oxygen are expressed as $\delta$ (per mil) ratio of samples relative to Vienna Standard Mean Ocean Water. The uncertainty of the $\delta^{2} \mathrm{H}$ and $\delta^{18} \mathrm{O}$ measurements were $\pm 2 \%$ and $\pm 0.2 \%$, respectively.

\subsection{Hydrograph Separation}

Hydrograph separation model is based on water balance and isotope equilibrium Equations (1) and (2):

$$
\begin{gathered}
Q_{t}=Q_{p}+Q_{e} \\
C_{t} Q_{t}=C_{p} Q_{p}+C_{e} Q_{e}
\end{gathered}
$$

where $Q_{t}$ denotes the streamflow at the outlet of the watershed, $Q_{p}$ represent pre-event water, which means the water stored in the experimental area prior to rainfall events. $Q_{e}$ is event water, which means rainfall input to Hemuqiao watershed. $C_{t}, C_{p}$ and $C_{e}$ represent tracer concentrations of streamflow, pre-event water and event water, respectively. The tracer concentration of pre-event water is replaced by the streamflow sample prior to the event the day before rainfall.

Before using conservative tracers to separate the hydrograph, there are several basic assumptions of isotopic hydrograph separation [40,41].

(1) The stable tracer composition of pre-event water and event water aresignificantly different.

(2) The stable tracer composition of rainfall and throughfall is constant in time and space, or variations of them can be measured.

(3) The isotope concentration in soil water can be negligible, or the isotope concentration in soil water is similar to the isotope concentration in groundwater. Soil water and groundwater are the main components of the pre-event water.

(4) Surface storage which contributes to stream at the outlet of the watershed could be ignored.

The contribution of pre-event water can be calculated by (1) and (2), so the proportion of pre-event water is expressed as follows:

$$
F=\frac{Q_{\mathrm{p}}}{Q_{\mathrm{t}}} \times 100 \%=\frac{C_{\mathrm{t}}-C_{\mathrm{e}}}{C_{\mathrm{p}}-C_{\mathrm{e}}} \times 100 \%
$$

where $F$ is the percentage of pre-event relative to the streamflow at the outlet of watershed.

\section{Results}

The characteristics of different type of rainfall events are summered in Table 1 . The type of rainfall is mainly defined by the cause of the precipitation events. Antecedent precipitation index represents can supplement relative soil moisture data series, and the day number of attenuation is 15 in Zhejiang province, China [42]. 
Table 1. Summary of rainfall events from 2015 to 2017 and the characteristics of precipitation condition.

\begin{tabular}{ccccccc}
\hline $\begin{array}{c}\text { Preicpitation } \\
\text { Events }\end{array}$ & Date & Type & $\begin{array}{c}\text { P-Total } \\
\text { Rainfall } \\
(\mathbf{m m})\end{array}$ & $\begin{array}{c}\text { Temperature } \\
\left({ }^{\circ} \mathbf{C}\right)\end{array}$ & $\begin{array}{c}\text { Rain } \\
\text { Intensity } \\
(\mathbf{m m} / \mathbf{h})\end{array}$ & $\begin{array}{c}\text { Antecedent } \\
\text { Precipitation } \\
\text { Index (mm) }\end{array}$ \\
\hline Storm 1 & 7-12 August 2015 & Typhoon rain & 126.8 & 25.75 & 5.12 & 4.07 \\
Storm 2 & 21-28 August 2015 & Typhoon rain & 47.6 & 29.30 & 0.80 & 45.41 \\
Storm 3 & 27 September 2015-2 October & Typhoon rain & 58.8 & 22.87 & 2.01 & 15.18 \\
Storm 4 & 22 June 2016-1 July 2016 & Plum rain & 132.0 & 21.80 & 2.24 & 45.91 \\
Storm 5 & 21-28 June 2017 & Plum rain & 65.8 & 23.15 & 0.46 & 36.64 \\
\hline
\end{tabular}

\subsection{Isotope Variation in Precipitation}

The isotope composition of different types of rainfall between 2015 and 2017 is shown in Table 2 from which we can clearly find that the variation of stable isotope during typhoon and plum rain events is in the variation of the stable isotope of precipitation in China [24].

Table 2. Stable isotope in typhoon and plum rain events from 2015-2017 and the range of $\delta^{18} \mathrm{O}$ and $\delta^{2} \mathrm{H}$ in precipitation in China.

\begin{tabular}{cccc}
\hline Parameter & Typhoon Rain & Plum Rain & $\begin{array}{c}\text { Stable Isotope of } \\
\text { Precipitation in China }\end{array}$ \\
\hline Range of $\delta^{18} \mathrm{O}(\%)$ & $-4.03--10.88$ & $-5.37--14.33$ & -24 to +2 \\
Range of $\delta^{2} \mathrm{H}(\%)$ & $-25.0--75.8$ & $-40.4--118.6$ & -190 to +20 \\
Standard Deviation of $\delta^{18} \mathrm{O}(\%)$ & 1.94 & 2.00 & na \\
Standard Deviation of $\delta^{2} \mathrm{H}(\%)$ & 14.97 & 15.83 & na \\
\hline
\end{tabular}

The isotopic value of precipitation in plum rain events is more depleted than that of precipitation in typhoon events. The reasons are probably: (1) the formation of rainfall: plum rain mainly due to the warm front from the ocean and the cold front from the north meet, which lasted for a long time. It can increase participation of depleted isotope tracer from fresh water through re-evaporated effect. Typhoon is mainly affected by tropical cyclones in the Pacific Ocean. The short-duration, heavy rainfall intensity and not being subject to being re-evaporated are the characteristics of typhoon rainfall events; (2) Migration time of water vapor: the marine air parcels of plum rain experience a long time from ocean to watershed, because of a handicap of a cold front. However, the marine air parcels of typhoon rain move very fast, and it takes only a few days for the marine air parcels to arrive at the experimental area. During the process of water vapor migration, the water vapor which enriched with heavy isotopes preferentially condenses into raindrop, then the raindrops fall to the ground. The stable isotopic composition of precipitation gradually decrease may be due to the strong and continuous rainout effect of the original marine air parcels.

\subsection{Local Meteoric Water Line}

Craig [43] discovered the relationship between ${ }^{2} \mathrm{H}$ and ${ }^{18} \mathrm{O}$ in precipitation through the study of meteoric water around the world, which is defined as the Global Meteoric Water Line (GMWL): $\delta^{2} \mathrm{H}$ $=8 \delta^{18} \mathrm{O}+10$. The GMWL plays a significant role in study of the hydrological cycle. The gradient of GMWL represents the rate of stable isotope $\left({ }^{2} \mathrm{H}\right.$ and $\left.{ }^{18} \mathrm{O}\right)$ fractionation, and the $\delta^{2} \mathrm{H}$-intercept reflects the deviation from the ${ }^{2} \mathrm{H}$ equilibrium state. Due to the difference between stable isotope fractionation factors from water vapor source to rainfall event occurrence, Local Meteoric Water Line (LMWL) is different from other areas. The LMWL is so important in studying the source of water and exploring the field of groundwater recharge in experimental watershed.

In this study, the least square method is utilized to calculate the data of stable isotope tracer during typhoon and plum rain events from 2015 to 2017, respectively (Figure 2). The relationship between stable isotope ${ }^{2} \mathrm{H}$ and ${ }^{18} \mathrm{O}$ during typhoon and plum rain are expressed as $\delta^{2} \mathrm{H}=7.63 \delta^{18} \mathrm{O}+$ $7.47\left(R^{2}=0.9818 n=47\right)$ and $\delta^{2} \mathrm{H}=7.51 \delta^{18} \mathrm{O}+5.10\left(\mathrm{R}^{2}=0.9013 n=68\right)$, respectively. The gradient and 
$y$-intercept of the Local Meteoric Water Line of typhoon events is significantly higher than that of the plum rain events. The gradient and $\delta^{2} \mathrm{H}$-intercept of the Local Meteoric Line during typhoon and plum rain events approximate to 8 and 10, respectively. This indicated that the two forms of rainfall during the summer are mainly affected by ocean water vapor. However, the Hemuqiao LMWL is different from the LMWL of Nanjing, where LMWL in summer from June to September is $\delta^{2} \mathrm{H}=8.11 \delta^{18} \mathrm{O}$ $+12.56\left(R^{2}=0.87\right)$ [24]. This is mainly because we only study the typhoon and plum rain events, without considering other forms of rainfall during summer such as orographic rain, thundershower and convectional rain. This is because it is difficult for us to take samples in short-duration rainfall with heavy rainfall intensity and uncertainty of occurrence time.

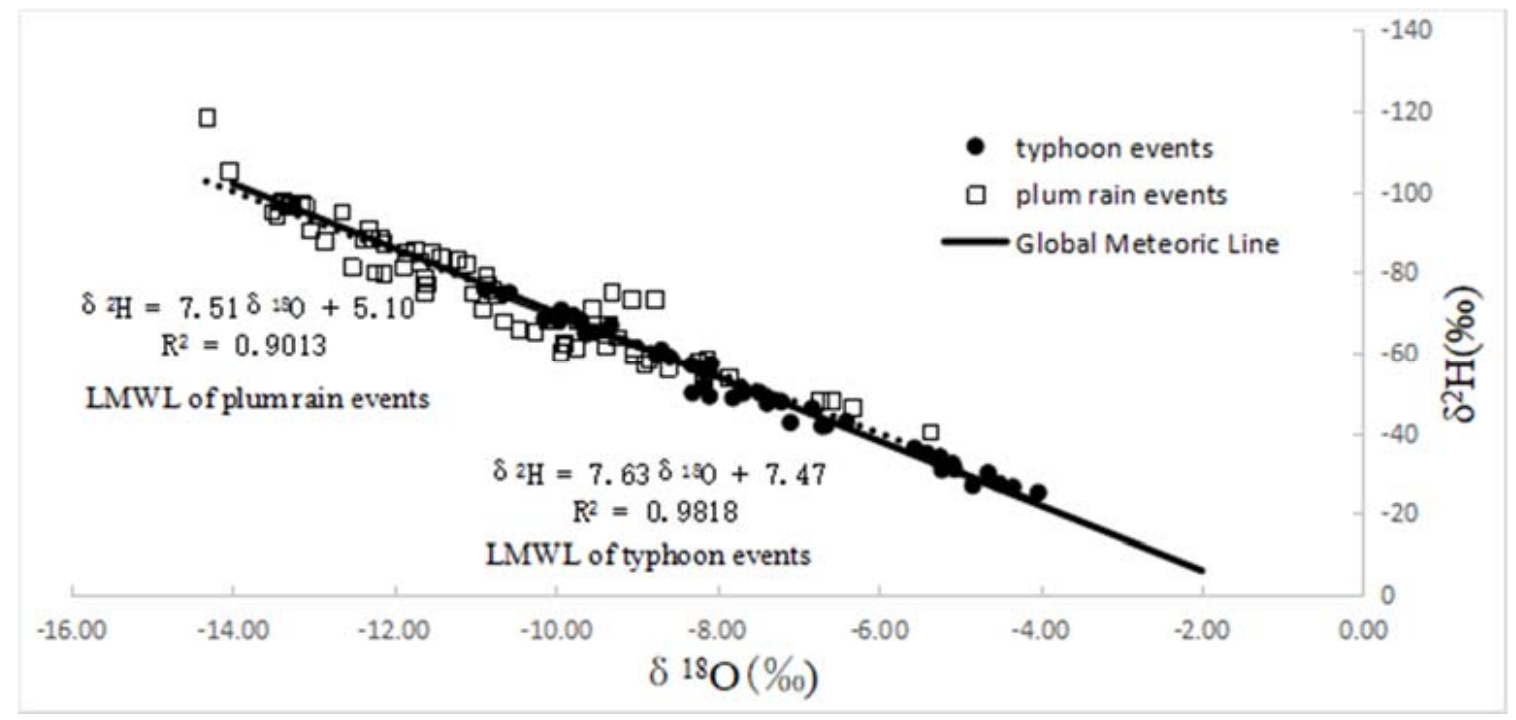

Figure 2. Plots of isotopic compositions of precipitation samples. The LMWL is based on the typhoon rainfall samples and the plum rain event samples, respectively. Note $R^{2}$ is the coefficient of determination.

\subsection{Deuterium Excess}

Deuterium excess was discovered by Dansgarard [19] which is expressed as $\mathrm{d}=\delta^{2} \mathrm{H}-8 \delta^{18} \mathrm{O}$. The d-excess can provide additional information for the formation of rainfall, identifying the secondary effect in the condensation-evaporation processes and determining the source of atmospheric vapor. Equilibrium process will not affect the d-excess in any conditions, but non-equilibrium evaporation under limited conditions will reduce the d-excess of the water which excludes the influence of exchanges with atmospheric vapor factor. In fact, non-equilibrium evaporation occurs on an unlimited and uniform mixture of ocean surface, d-excess is remaining constant. The most important factors affecting the d-excess are the variation of temperature and relative humidity during the evaporation process.

As we can see from Figure 3 and Table 3, comparing the two different types of rain events, we can clearly find that mean and range of d-excess in typhoon events is relatively small, and the isotopic composition of rainfall collected in plum rain events has a more wide range of d-excess than that in typhoon events. The d-excess of typhoon events is relatively close to 10 , in other words close to the ocean water evaporation value. This indicates that the secondary evaporation of water vapor from the surface of the ocean to experimental watershed can be neglected. 


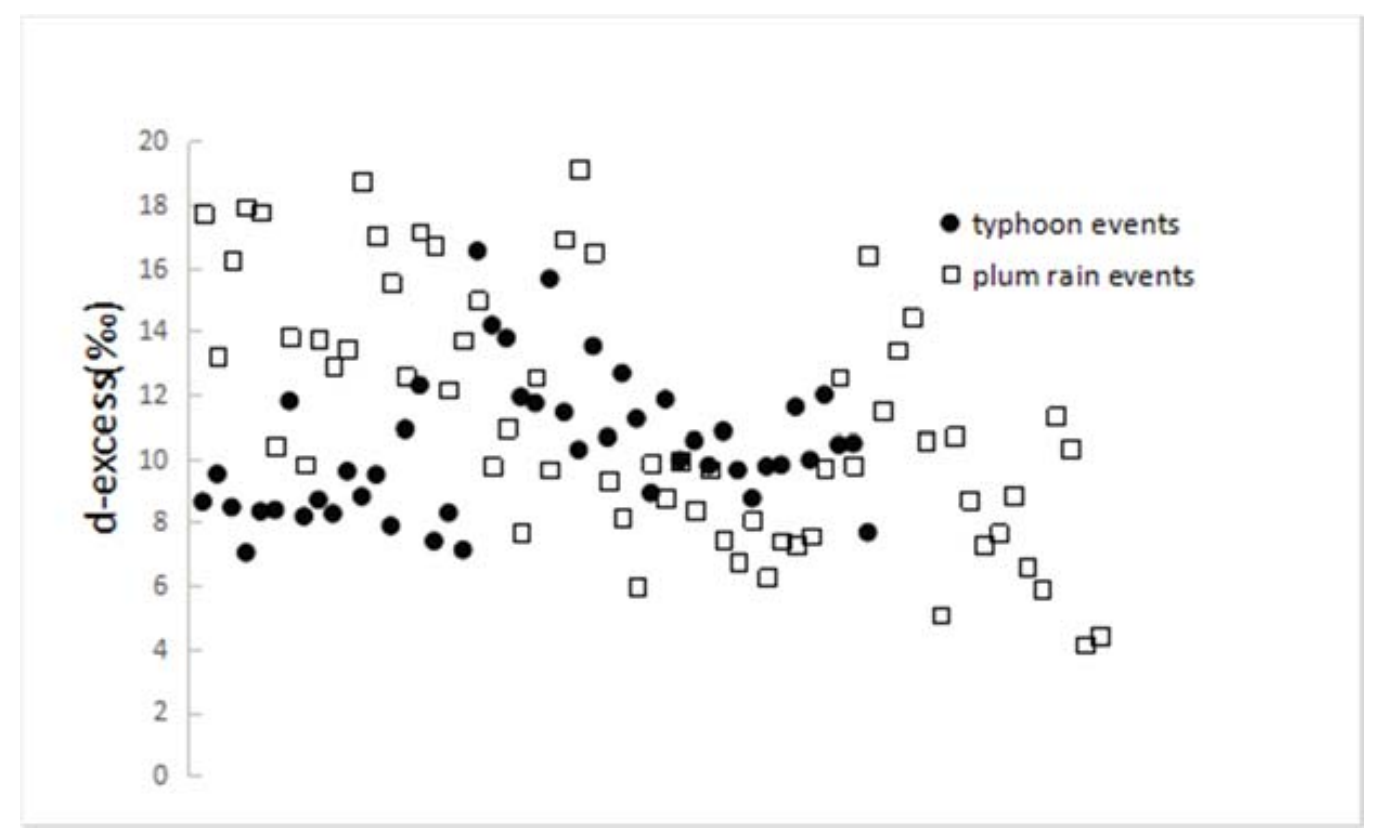

Figure 3. Plots of d-excess in typhoon events and the plum rain events at Hemuqao watershed during 2015-2017.

Table 3. D-excess in typhoon and plum rain events during 2015-2017.

\begin{tabular}{ccc}
\hline Parameter & Typhoon Rain & Plum Rain \\
\hline Range of d-excess & 7.03 to 16.53 & 4.07 to 19.12 \\
Arithmetically average & 10.31 & 11.12 \\
Standard Deviation of d-excess & 2.15 & 3.95 \\
\hline
\end{tabular}

\subsection{Hydrograph Separations}

In the process of water circulation of Hemuqiao watershed, the changes of meteorological parameters will cause various water sources (precipitation, surface water, groundwater and streamflow) fractionation in condensation, evaporation and exchange process. The time series of stable isotopes of concentration in various water sources can be used to calculate the proportion of pre-event water in discharge hydrograph during the course of rain events. From the five rainfall events, one (storm 5) is excluded because no corresponding discharge data at the outlet of the watershed were obtained during the writing period. Therefore, only four rain events that occurred in 2015-2016 were used to conduct the one-tracer two component hydrograph separation analyses including three typhoon events and one plum rain event. The influence of direct rainfall on the river network or impervious surface (concrete pavement) has not been determined, because it may not be the primary path for the event water to enter the streamflow.

The results of the hydrograph separation analysis which is presented in Figure 4 indicate that the pre-event water component $Q_{e}$ accounted for the majority of the streamflow at the outlet of the watershed. The difference in proportion of pre-event water and rainfall-runoff response can be used to study the runoff generation mechanism influencing factors such as characteristics of rainfall, initial state of watershed and geologic features. 

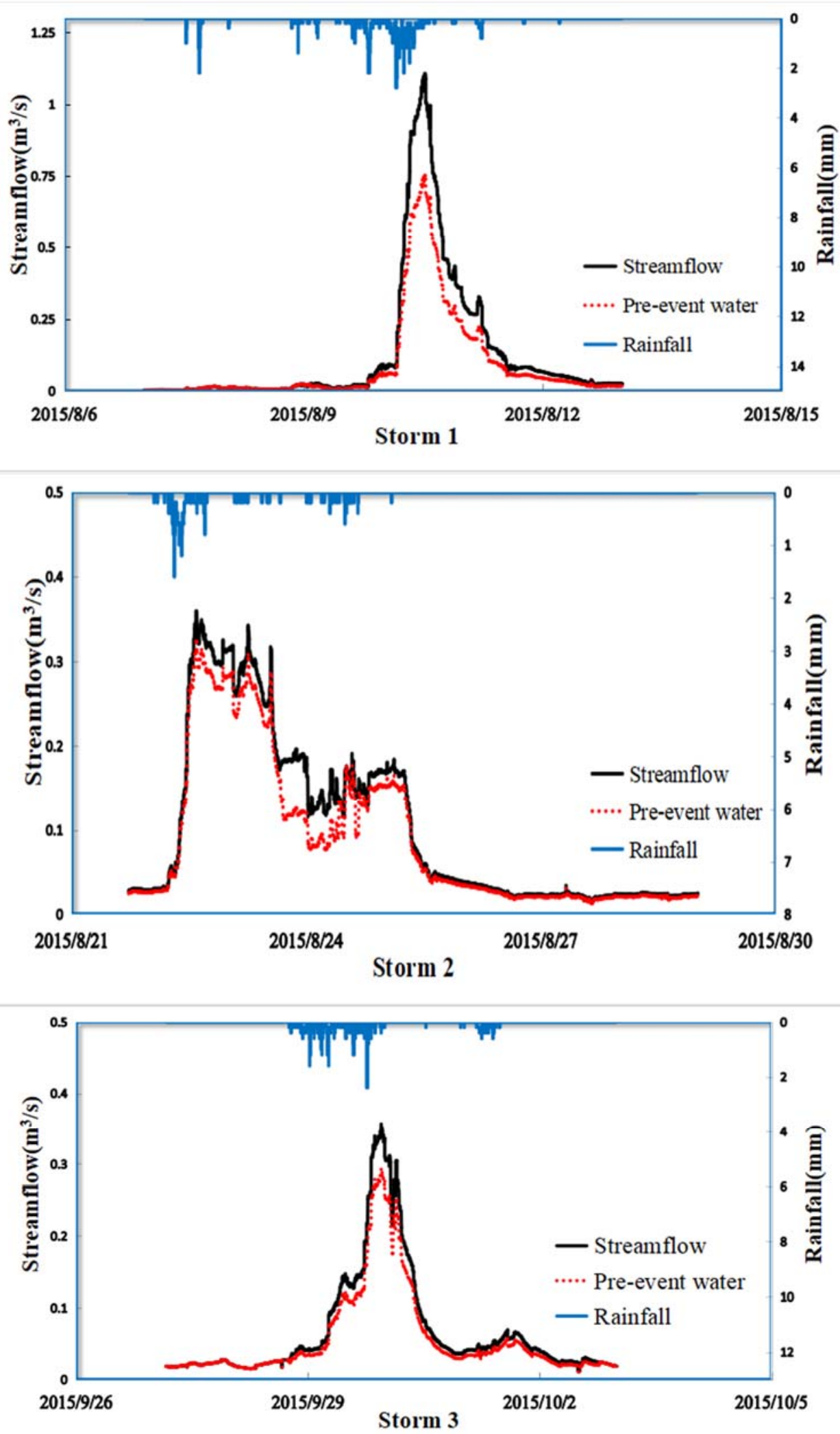

Figure 4. Cont. 


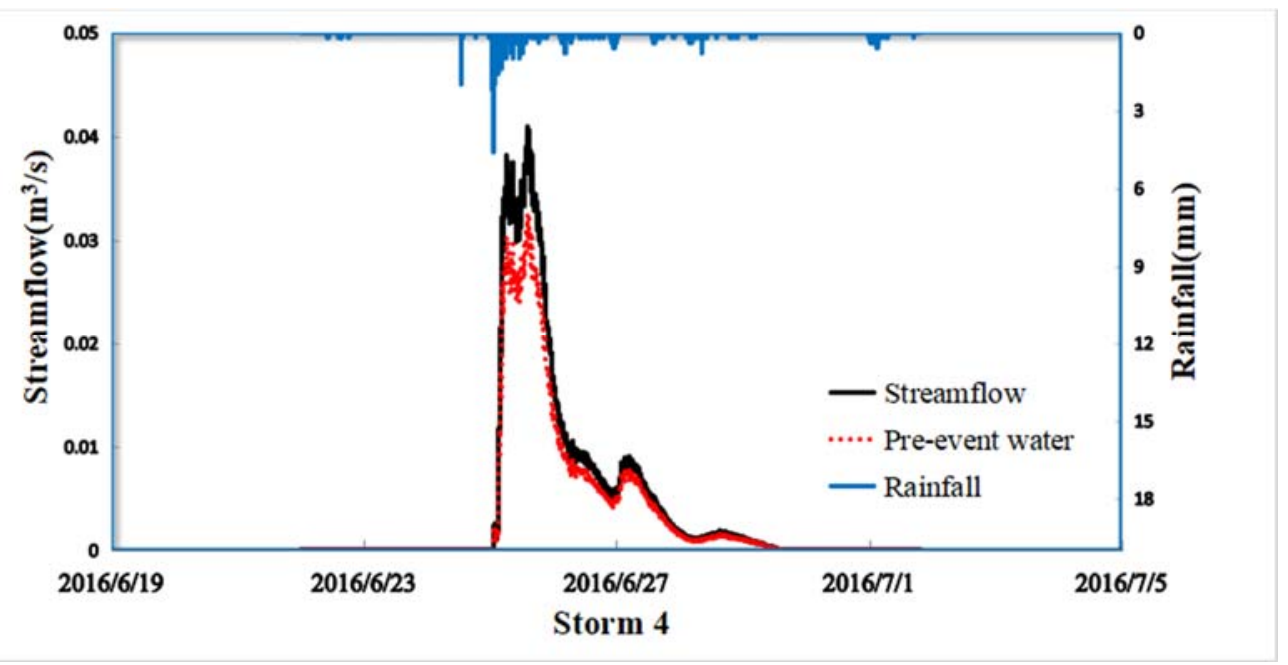

Figure 4. Two-component hydrograph separations are used to quantify pre-event water contribution by $\delta^{18} \mathrm{O}$ for four storms from 2015-2016. The area below the red dotted line depicts the pre-event water and the area above depicts the event water.

The first storm event is caused by the Soudelor typhoon between 7-12 August 2015. As the watershed is close to the center of the storm, the total precipitation and rainfall intensity are quite large. At the beginning of rainfall, there is no obvious change in discharge because the antecedent precipitation index in the last 15 days before this rainfall event is just $4.07 \mathrm{~mm}$ which can be ignored. Before the typhoon event, the base flow discharge is about $0.003 \mathrm{~m}^{3} / \mathrm{s}$, which indicates quite dry antecedent soil moisture. After about $48.8 \mathrm{~mm}$ precipitation, the discharge at the outlet of Hemuqiao watershed exhibits an obviously upward trend. With the process of rainfall event, the discharge in the channel starts to increase significantly at 4:00 p.m. on 10 August 2015, and at 12:30 a.m. on the next day the discharge and pre-event water reach the peak (peak discharge is $1.1 \mathrm{~m}^{3} / \mathrm{s}$ ). At the peak flow, the pre-event water accounts for $60.9 \%$ of the instantaneous discharge. The peak time of streamflow lagged behind the peak time of the precipitation by about $4.6 \mathrm{~h}$. Subsequently, rain intensity starts to decrease and disappear soon. In the decreasing phase, the discharge responds rapidly to the $6.2 \mathrm{~mm}$ precipitation which occurs between 4:05 p.m. and 5:59 p.m. on 11 August 2015 indicating saturated soil moisture content. During the following time, the discharge decreases rapidly to the initial state of the channel. The total contribution of pre-event is about $67.9 \%$ which is the minimum of four rainfall events.

The second storm event is caused by Goni typhoon between 21-27 August 2015. The typhoon moved northward along the interface between the East China Sea and the Pacific Ocean which leads to the watershed away from the center of the storm. The total precipitation and intensity of the second storm event are the smallest. At the beginning of rainfall, there is an obvious change in discharge in response to rainfall because the antecedent precipitation index is $45.41 \mathrm{~mm}$ in the last 15 days before this rainfall event. The discharge in the channel quickly reaches the peak $\left(0.359 \mathrm{~m}^{3} / \mathrm{s}\right)$ and synchronously the pre-event water follows the same trend. At the peak flow, the pre-event water accounts for $90 \%$ of the instantaneous discharge. With the progress of the rainfall event, the discharge responding in the channel shows a significant trend of fluctuating downward which was influenced by discontinuous rainfall. The discharge at the outlet of the watershed decreases to a steady state which is closed to the discharge before this typhoon event, about $51.3 \mathrm{~h}$ after the end of the rainfall event. The lag time between the peak time of streamflow and that of precipitation is about $6.8 \mathrm{~h}$ and the contribution of pre-event is about $98.3 \%$ which is the maximum of four rainfall events.

The third storm event is due to Dujuan typhoon between 27 September and 2 October 2015. The total precipitation and intensity of this storm event are 58.8 and $0.8 \mathrm{~mm} / \mathrm{h}$, respectively. There is a 
small discharge in the channel (about $0.02 \mathrm{~m}^{3} / \mathrm{s}$ ) prior to rainfall event, and the discharge increases with the increase of precipitation. About $21.6 \mathrm{~h}$ after the start of the rainfall event, the discharge in the channel reaches the peak $\left(0.356 \mathrm{~m}^{3} / \mathrm{m}\right)$. At the peak flow, the pre-event water accounts for $82 \%$ of the instantaneous discharge. We can clearly see that the discharge gradually decreases to the initial state after rainfall stops. The discharge in the channel immediately responded to the 1 October precipitation event, which indicated that the continuous rainfall will cause the soil water content to reach saturation in the watershed. The lag time between the peak time of streamflow and that of precipitation is about $4.2 \mathrm{~h}$ and the total contribution of pre-event is about $81.6 \%$.

The last plum rain event occurs mainly due to the warm front from the ocean and the cold front from the north meet, which lasted for a long time (22-28 June 2016). Streamflow response to this event is typically in the form of a double-peak hydrograph with a sudden rise or fall during the course of events. Generally speaking, the discharge response to precipitation can be considered as rapid response. Antecedent precipitation index in the last 15 days $(45.91 \mathrm{~mm})$ before this rainfall is the maximum of four rainfall events, and this indicates that the initial soil moisture content in the watershed is very high. The discharge of the river increases rapidly from 0 to $0.037 \mathrm{~m}^{3} / \mathrm{s}$ after the $16.6 \mathrm{~mm}$ rainfall and then rapidly decreases to $0.030 \mathrm{~m}^{3} / \mathrm{s}$ in the next $3 \mathrm{~h}$. With the process of the rainfall event, the discharge rapidly increases to the peak of $0.41 \mathrm{~m}^{3} / \mathrm{s}$ within the next $4.8 \mathrm{~h}$. At the peak flow, the pre-event water accounts for $79 \%$ of the instantaneous discharge at the outlet of the Hemuqiao watershed. The lag time between the peak time of streamflow and that of precipitation is about $13 \mathrm{~h}$ and the total contribution of pre-event is about $84.0 \%$.

\section{Discussion}

\subsection{Relationship between Deuterium and Oxygen-18 in Precipitation}

Based on the study of stable isotopes $\left(\delta^{2} \mathrm{H}\right.$ and $\left.\delta^{18} \mathrm{O}\right)$ during typhoon and plum rain events in Hemuqiao watershed in the monsoon area in southeast China, it shows that the stable isotope tracer of precipitation during rainfall events has significantly changed. The results of variation suggest that three factors may affect the isotope composition of precipitation.

(1) Characteristics of ocean surface water vapor. Hydrologists tried to roughly calculate the mean stable isotope concentrate of ocean atmosphere systems under closed conditions with mean humidity of $75 \%$ which is based on the assumption that the isotope tracer of evaporative flux and precipitation are the same $\left(\delta^{18} \mathrm{O}=-4 \%\right.$ and $\left.\delta^{2} \mathrm{H}=-22 \%\right)$. In practice, based on the isotope data collected by IAEA-WMO precipitation network, the average isotopic concentration of the ocean precipitation is $\delta^{18} \mathrm{O}=-2.5 \%$ to $3 \%$ which assume isotopic fractionation of saline water under equilibrium condition with a temperature of $20^{\circ} \mathrm{C}$. However, as the temperature of ocean surface has seasonal variation, the air-water interaction conditions also change. Typhoon events during August and September are mainly caused by frequent temperate and tropical cyclones whose evaporation of ocean water is expected to be very strong. We can deduce that the rate of water vapor diffusion is greater than the rate of the condensation in the air-water interaction zone. The surface temperature of the ocean is relatively high with a high net evaporation flux which indicated that the isotope composition of water vapor is more depleted than average isotopic concentration of ocean precipitation. Nevertheless, for plum rain event, the isotopic concentration of water vapor from the surface of the ocean may not be the most significant factor because of the time it takes for marine air parcels to reach the watershed.

(2) Migration of marine air parcels. As the marine air parcel moves over the ocean into the continents, different vapor clouds undergo different processes in storm trajectories. The plum rain event is identified as mainly controlled by Southwest and Southeast monsoon which refers to the warm and humid marine air parcel. During the monsoon season, the Northwest wind gradually weaken while the summer monsoon strengthen. Due to the blocking effect of the cold front, warm and humid marine air parcels climb along the cold front slowly which will lead to the temperature of 
marine air parcel reducing and the subsequent occurrence of the plum rain events. In addition, the marine air parcel moves slowly along the terrestrial part of hydrology cycle which indicates that the air moisture evaporated from the continent will play a significant role in the isotope of precipitation dilution process. However, marine air parcels of typhoon rain move very quickly; they only take a few days to reach the Hemuqiao watershed. The increasing water vapor from the re-evaporated fresh water with relatively depleted isotope concentration can be neglected, but the continuous rainout effect is known to be a dominant factor in depleting the stable isotope concentration of marine air parcel.

(3) Exchange and evaporation effect. During the rainfall, the exchange effect between falling raindrops and atmospheric water vapor cannot be ignored. During the course of plum rain events, the air parcel lifted to a high altitude with very low temperature, and then water vapor condenses into raindrops which fall into ground rapidly. The exchange effect also occurred in the clouds, which will result in the establishment of isotopic equilibrium with relatively depleted environmental vapor. Then, with raindrops falling from the cloud to the watershed, exchange and evaporation effect also take place between raindrops and ambient air. The character of plum rain is long-time small rainfall intensity, which has more obvious exchange and evaporation effect, so the stable isotope tracer of precipitation in plum rain events is relative depleted. However, for typhoon events, the character is short-time heavy rain which makes exchange and evaporation effect relatively less notable.

\subsection{Runoff Generation Mechanism}

The results of the hydrograph separation analysis reveal that the pre-event water is the most important component to discharge at the outlet of the watershed in different types of rain event. The different proportion may be the key to exploring the process of runoff generation factors in Hemuqiao experimental watershed.

To study the characteristics of four rainfall events, we can clearly find that the rainfall intensity has a significant temporal change. In the process of rainfall events, the rain intensity is less than the infiltration capacity at some times and sometimes greater than the infiltration capacity. When rainfall intensity is greater than soil infiltration capacity, excess infiltration will occur in places where the soil water content reached the saturated moisture content, which will increase the proportion of event water to the total discharge in the channel (storm 1). Rainfall intensity of storm 2 is the smallest that will result in the raindrops in the ground infiltrating along the vertical section of the soil layer. Infiltration of the event water will replace the pre-event water in the unsaturated or saturated zone, making the percentage of pre-event water contribution to discharge larger, and precipitation relative to the watershed water storage capacity can be ignored, so the event water cannot completely replace the pre-event water. The remaining event water contribution of $1.7 \%$ in storm 2 may be mainly due to the direct rainfall onto the channel or impervious surface which will rapidly collect to a watershed export as event water.

The contribution of pre-event water also related to the characteristics of landscape organization. Hemuqiao experimental watershed is located in the humid mountainous area of Southeast China, which has a relatively thin thickness of unsaturated zone $(1.5-2.5 \mathrm{~m})$ and high permeable soil covered well with plants. The main runoff generation pattern of this region is repletion of storage, which means that runoff is generated until soil moisture reaches field capacity, and the excess rainfall will flow out of the watershed as event water. However, this theory may be not used to reveal the runoff process in mountainous watershed covered with bamboo. Storm 2 has relatively wet antecedent condition and shows the highest proportion of pre-event water which indicates that the growth and development of plant roots might probably result in macropore flow being widespread in bamboo forest soil.

Hemuqiao watershed is covered mainly by bamboo $(90 \%)$, and the rest is covered by potato, tea and other crops. The vegetation cover is one of the important factors which impacts the proportion of pre-event water. Liu et al. [44] investigate the runoff generation in small catchments with a native rain 
forest and a rubber plantation in southwestern China, and discover that the variation in vegetation cover have a significant impact on the proportion of pre-event water. Qu et al. [45] investigate the variation of isotope composition in precipitation, and discover that the stable isotopic value exhibit differences in the chestnut wood and bamboo area. The vegetation cover influences the proportion of pre-event water mainly by the interception of forest canopy and the change in soil structure. The interception of bamboo canopy is different from the interception of other crops, which may change the isotopic value of throughfall. The different isotopic value of throughfall means different isotopic value in event water. The proportion of pre-event water which calculated by Equation 3 must be different. The soil structure mainly affects the retention capacity of event water during the rainfall events. In order to explore the comprehensive response of Hemuqiao watershed which mainly covered with bamboo, we do not discuss in detail the effects of other crops.

\section{Conclusions}

The purpose of hydrometric observations in southeastern China is to explore the runoff generation mechanism and variation of isotope in precipitation in the mountainous region mainly covered with bamboo. The stable isotope tracer of precipitation in plum rain events is relatively depleted compared with that in typhoon events and isotopic composition of rainfall collected in plum rain events has a more wide range of $d$-value than that in typhoon events. These results suggest that the combined influence of characteristics of ocean surface water vapor, migration of marine air parcels and exchange and evaporation effect during event may be the key to the variation of stable isotopic composition of precipitation. The gradient and y-intercept of the Local Meteoric Water Line during typhoon and plum rain events approach eight and ten, respectively. This indicated that the two forms of rainfall during summer were mainly affected by ocean water vapor. The results of the hydrograph separation analysis indicate that the pre-event water component accounted for at least $60 \%$ of the discharge at the outlet of the watershed. The difference in proportion of pre-event water and rainfall-runoff response in different types of rain events suggests that the initial state of watershed, rainfall intensity and macropore flow are major controlling factors for the runoff production mechanism.

Author Contributions: Jianfeng Gou, Dachen Li, Xueqiu Chen, Yifan Wang, Shuai Shan, Wei Si took the water samples; Yifan Wang and Shuai Shan analyzed the data; Simin Qu, Peng Shi and Jianfeng Gou wrote the paper.

Funding: The study is financially supported by the National Key Research and Development Program of China (2016YFC0402703), the National Natural Science Foundation of China (No. 41371048, 51479062, 40901015, 51709077), the Fundamental Research Funds for the Central Universities (2017B10914), the National Postdoctoral Foundation of China (2017M611679), the Postdoctoral Foundation of Jiangsu Province (1701019A).

Conflicts of Interest: The authors declare that they have no conflict of interest.

\section{References}

1. Gat, J.R. Oxygen and hydrogen isotopes in the hydrologic cycle. Annu. Rev. Earth Planet. Sci. 1996, 24, 225-262. [CrossRef]

2. Qu, S.M.; Bao, W.M.; McDonnell, J.J.; Yu, Z.B.; Shi, P. Isotope tracer in watershed hydrological modeling. Adv. Water Sci. 2008, 19, 587-596. (In Chinese)

3. Sklash, M.G.; Farvolden, R.N. The role of groundwater in storm runoff. J. Hydrol. 1979, 43, 45-65. [CrossRef]

4. Onda, Y.; Tsujimura, M.; Fujihara, J.I.; Ito, J. Runoff generation mechanisms in high-relief mountainous watersheds with different underlying geology. J. Hydrol. 2006, 331, 659-673. [CrossRef]

5. McDonnell, J.J.; Sivapalan, M.; Vaché, K.; Dunn, S.; Grant, G.; Haggerty, R.; Hinz, C.; Hooper, R.; Kirchner, J.; Roderick, M.L. Moving beyond heterogeneity and process complexity: A new vision for watershed hydrology. Water Resour. Res. 2007, 43, 931-936. [CrossRef]

6. Rodgers, P.; Soulsby, C.; Waldron, S. Stable isotope tracers as diagnostic tools in upscaling flow path understanding and residence time estimates in a mountainous mesoscale catchment. Hydrol. Process. 2005, 19, 2291-2307. [CrossRef] 
7. McGuire, K.J.; McDonnell, J.J.; Weiler, M.; Kendall, C.; McGlynn, B.L.; Welker, J.M.; Serbert, J. The role of topography on catchment-scale water residence time. Water Resour. Res. 2005, 41, 302-317. [CrossRef]

8. Mueller, M.H.; Weingartner, R.; Alewell, C. Importance of vegetation, topography and flow paths for water transit times of base flow in alpine headwater catchments. Hydrol. Earth Syst. Sci. 2013, 17, 1661-1679. [CrossRef]

9. Segura, C.; James, A.L.; Lazzati, D.; Roult, N.T. Scaling relationships for event water contributions and transit times in small-forested catchments in Eastern Quebec. Water Resour. Res. 2012, 48, 7502. [CrossRef]

10. Buttle, J.M. Fundamentals of small catchment hydrology. In Isotope Tracers in Catchment Hydrology; McDonell, J.J., Kendall, C., Eds.; Elsevier: Amsterdam, The Netherlands, 1998; pp. 1-49.

11. Burns, D.A.; McDonnell, J.J.; Hooper, R.P.; Peters, N.E.; Freer, J.E.; Kendall, C.; Beven, K. Quantifying contributions to storm runoff through end-member mixing analysis and hydrologic measurements at the Panola Mountain Research Watershed (Georgia, USA). Hydrol. Process. 2001, 15, 1903-1924. [CrossRef]

12. Małoszewski, P.; Zuber, A. Determining the turnover time of groundwater systems with the aid of environmental tracers: 1. Models and their applicability. J. Hydrol. 1982, 57, 207-231. [CrossRef]

13. Herczeg, A.L.; Barnes, C.J.; Macumber, P.G.; Olley, J.M. A stable isotope investigation of groundwater-surface water interactions at Lake Tyrrell, Victoria, Australia. Chem. Geol. 1992, 96, 19-32. [CrossRef]

14. Matsuo, S.; Friedman, I. Deuterium content in fractionally collected rainwater. J. Geophys. Res. 1967, 72, 1-12. [CrossRef]

15. Matsui, E.; Salati, E.; Ribeiro, M.N.G.; Reis, C.M.; Tancredi, A.C.S.N.F.; Gat, J.R. Precipitation in the central amazon basin: The isotopic composition of rain and atmospheric moisture at Belém and Manaus. Acta Amazon. 1983, 13, 307-369. [CrossRef]

16. Ohsawa, S.; Yusa, Y. Isotopic characteristics of typhonic rainwater: Typhoons No. 13 (1993) and No. 6 (1996). Limnology 2000, 1, 143-149. [CrossRef]

17. Siegenthaler, U.; Oeschger, H. Correlation of ${ }^{18} \mathrm{O}$ in precipitation with temperature and altitude. Nature 1980, 285, 314-317. [CrossRef]

18. Poage, M.A.; Chamberlain, C.P. Empirical relationships between elevation and the stable isotope composition of precipitation and surface waters: Considerations for studies of paleoelevation change. Am. J. Sci. 2001, 301, 1-15. [CrossRef]

19. Dansgaard, W. Stable isotopes in precipitation. Tellus 1964, 16, 436-468. [CrossRef]

20. Craig, H.; Gordon, L.I. Deuterium and oxygen 18 variations in the ocean and marine atmosphere. In Proceedings of the Stable Isotopes in Oceanographic Studies and Paleotemperatures, Spoleto, Italy, 1965; Tongiogi, E., Ed.; Consiglio Nazionale Delle Richerche, Laboratorio di Geologia Nucleare, V. Lishi e F. Publ.: Pisa, Italy, 1965; pp. 9-130.

21. Rindsberger, M.; Magaritz, M.; Carmi, I.; Gilad, D. The relation between air mass trajectories and the water isotope composition of rain in the Mediterranean Sea area. Geophys. Res. Lett. 2013, 10, 43-46. [CrossRef]

22. Galewsky, J.; Steen-Larsen, H.C.; Field, R.D.; Worden, J.; Risi, C.; Schneider, M. Stable isotopes in atmospheric water vapor and applications to the hydrologic cycle. Rev. Geophys. 2016, 54, 809-865. [CrossRef]

23. Yu, W.S.; Wei, F.L.; Ma, Y.M.; Liu, W.J.; Zhang, Y.Y.; Luo, L.; Tian, L.; Xu, B.Q.; Qu, D.M. Stable isotope variations in precipitation over Deqin on the southeastern margin of the Tibetan Plateau during different seasons related to various meteorological factors and moisture sources. Atmos. Res. 2016, 170, 123-130. [CrossRef]

24. Wang, T.; Zhang, J.R.; Liu, X.; Yao, L. Variations of stable isotopes in precipitation and water vapor sources in Nanjing area. J. China Hydrol. 2013, 33, 25-31. (In Chinese)

25. Dinçer, T.; Payne, B.R.; Florkowski, T.; Martinec, J.; Tongiorgi, E. Snowmelt runoff from measurements of tritium and oxygen-18. Water Resour. Res. 1970, 6, 110-124. [CrossRef]

26. Fritz, P.; Cherry, J.A.; Sklash, M.; Weyer, K.U. Storm runoff analysis using environmental isotopes and major ions. Panel Proc. Ser. Int. Atomic Energy Agency 1976, 36, 13-24.

27. Vitvar, T.; Aggarawal, P.K.; McDonnell, J.J. A review of isotope applications in catchment hydrology. In Isotopes in the Water Cycle: Present and Future of a Developing Science; Aggarwal, P.K., Gat, J.R., Froehlich, K.F.O., Eds.; Springer: Dordrecht, The Netherlands, 2005; pp. 151-169.

28. Boy, J.; Valarezo, C.; Wilcke, W. Water flow paths in soil control element exports in an Andean tropical montane forest. Eur. J. Soil Sci. 2008, 59, 1209-1227. [CrossRef] 
29. Niedzialek, J.M.; Ogden, F.L. First-order catchment mass balance during the wet season in the Panama Canal Watershed. J. Hydrol. 2012, 462-463, 77-86. [CrossRef]

30. Klaus, J.; McDonnell, J.J. Hydrograph separation using stable isotopes: Review and evaluation. J. Hydrol. 2013, 505, 47-64. [CrossRef]

31. Shanley, J.B.; Kendall, C.; Smith, T.E.; Wolock, D.M.; McDonnell, J.J. Controls on old and new water contributions to stream flow at some nested catchments in Vermont, USA. Hydrol. Process. 2002, 16, 589-609. [CrossRef]

32. Gomi, T.; Asano, Y.; Uchida, T.; Onda, Y.; Sidle, R.C.; Miyata, S.; Kosugi, K.; Mizugaki, S.; Fukuyama, T.; Fukushima, T. Evaluation of storm runoff pathways in steep nested catchments draining a Japanese cypress forest in central Japan: A geochemical approach. Hydrol. Process. 2010, 24, 550-566. [CrossRef]

33. McDonnell, J.J. A rationale for old water discharge through macropores in a steep, humid catchment. Water Resour. Res. 1990, 26, 2821-2832. [CrossRef]

34. Stumpp, C.; Stichler, W.; Maloszewski, P. Application of the environmental isotope $\delta^{18} \mathrm{O}$ to study water flow in unsaturated soils planted with different crops: Case study of a weighable lysimeter from the research field in Neuherberg, Germany. J. Hydrol. 2009, 368, 68-78. [CrossRef]

35. Vivoni, E.R.; Entekhabi, D.; Bras, R.L.; lvanov, V.Y. Controls on runoff generation and scale-dependence in a distributed hydrologic model. Hydrol. Earth Syst. Sci. 2007, 11, 1683-1701. [CrossRef]

36. James, A.L.; Roulet, N.T. Antecedent moisture conditions and catchment morphology as controls on spatial patterns of runoff generation in small forest catchment. J. Hydrol. 2009, 377, 351-366. [CrossRef]

37. Monteith, S.S.; Buttle, J.M.; Hazlett, P.W.; Beall, F.D.; Semkin, R.G.; Jeffries, D.S. Paired-basin comparison of hydrological response in harvested and undisturbed hardwood forests during snowmelt in central Ontario: I. Streamflow, groundwater and flowpath behaviour. Hydrol. Process. 2010, 20, 1095-1116. [CrossRef]

38. Pellerin, B.A.; Wollheim, W.M.; Feng, X.; Vörösmarty, C.J. The application of electrical conductivity as a tracer for hydrograph separation in urban catchments. Hydrol. Process. 2008, 22, 1810-1818. [CrossRef]

39. Feng, D.; Liu, J.; Chen, X. Spatial variation of hillslope soil chemical attributes. J. Mt. Sci. 2011, 29 , 427-432. (In Chinese)

40. Sklash, M.G.; Farvolden, R.N.; Fritz, P. Erratum: A conceptual model of watershed response to rainfall, develop. Can. J. Earth Sci. 1976, 63, 1016-1020.

41. Buttle, J.M. Isotope hydrograph separations and rapid delivery of pre-event water from drainage basins. Prog. Phys. Geogr. 1994, 18, 16-41. [CrossRef]

42. Zhao, Y.; Wei, F.; Yang, H.; Jiang, Y. Discussion on using antecedent precipitation index to supplement relative soil moisture data series. Procedia Environ. Sci. 2011, 10, 1489-1495. [CrossRef]

43. Craig, H. Isotopic variation in meteoric waters. Science 1961, 133, 1702-1703. [CrossRef] [PubMed]

44. Liu, W.; Liu, W.; Lu, H.; Duan, W.; Li, H. Runoff generation in small catchments under a native rain forest and a rubber plantation in xishuangbanna, southwestern china. Water Environ. J. 2011, 25, 138-147.

45. Qu, S.M.; Shan, S.; Chen, X.; Zhou, M.M.; Liu, H. Isotopic analysis of water cycle elements in different land covers in a small headwater watershed. Water Policy 2017, 19, wp2017244. [CrossRef]

(C) 2018 by the authors. Licensee MDPI, Basel, Switzerland. This article is an open access article distributed under the terms and conditions of the Creative Commons Attribution (CC BY) license (http:/ / creativecommons.org/licenses/by/4.0/). 